Chatfield, C. \& Adams, G. (1940). Circ. U.S. Dep. Agric. no. 549.

Commonwealth of Australia: Advisory Council on Nutrition (1938). Fifth Report. Canberra: Commonwealth Government Printer.

Food and Agriculture Organization of the United Nations: Committee on Calorie Conversion Factors and Food Composition Tables (1947). Energy-yielding Components of Food and Computation of Calorie Values. Washington, U.S.A.: Food and Agriculture Organization of the United Nations.

Fox, F. W. \& Golberg, L. (1944). Publ. S. Afr. Inst. med. Res. 9, 123.

Imperial Bureau of Animal Nutrition. (1938). Tech. Commun. Bur. Anim. Nutr., Aberd., no. io.

Jones, D. B. (1931). Circ. U.S. Dep. Agric. no. 183 .

McCance, R. A. \& Walsham, C. M. (1948). Brit. F. Nutr. 2, 26.

McCance, R. A. \& Widdowson, E. M. (1940). Spec. Rep. Ser. med. Res. Coun., Lond., no. 235, ist ed.

McCance, R. A. \& Widdowson, E. M. (1946). Spec. Rep. Ser. med. Res. Coun., Lond., no. 235, 2 nd ed.

McCance, R. A. \& Widdowson, E. M. (1947). F. Hyg., Camb., 45, 59.

Macrae, T. F., Hutchinson, J. C. D., Irwin, J. C., Bacon, J. S. D. \& McDougall, E. I. (1942). F. Hyg., Camb., 42, 423.

Marston, H. R. \& Dawbarn, M. C. (1944). Bull. Coun. sci. industr. Res. Aust. no. I78.

Maynard, L. A. (1944). F. Nutr. 28, 443 .

Maynard, L. A. \& Galbraith, H. (1947). In Energy-yielding Components of Food and Computation of Calorie Values, Appendix A. (Food and Agriculture Organization of the United Nations: Committee on Calorie Conversion Factors and Food Composition Tables (1947). Washington, U.S.A.: Food and Agriculture Organization of the United Nations).

Medical Research Council: Accessory Food Factors Committee. (I945). M.R.C. (War) Memor. no. I4. Osmond, A. (1948). Spec. Rep. Ser. nat. Hlth med. Res. Coun., Canberra, no. 2.

Platt, B. S. (1945). Spec. Rep. Ser. med. Res. Coun., Lond., no. 253.

Plimmer, R. H. A. (I921). Analyses and Energy Values of Foods. London: H.M. Stationery Office.

Rubner, M. (1879). Z. Biol. I5, I 5.

Rubner, M. (1883). Z. Biol. x9, 45 .

Rubner, M. (1885). Z. Biol. 21, 250.

Rubner, M. (1901). Z. Bial. 42, 261 .

Sherman, H. C. (1928). Chemistry of Food and Nutrition, 3rd ed. New York: The Macmillan Co.

\title{
Some Difficulties in Estimating the Energy Value of Human Diets
}

\author{
By Dorothy F. Hollingsworth, Scientific Adviser's Division (Food), Ministry \\ of Agriculture, Fisheries and Food, Great Westminster House, Horseferry Road, \\ London, S.W.I
}

I intend to limit the difficulties for the purpose of this discussion to those likely to be met in estimating the energy value of human diets from tables of food composition.

There are several types of difficulty that might be classified as follows: (I) the problem of fitting the condition of the food to that to which the available average chemical analyses apply, (2) the problem of fitting the description of the food to that in the table of food composition, (3) difficulties relating to the method of expressing carbohydrate, (4) difficulties relating to the choice of factors for conversion of protein, fat, carbohydrate and other energy-yielding food constituents to calories. Errors can be made under some or all of these headings. Sometimes they compensate for each other: sometimes they do not.

The errors that might arise under the first heading seem almost too obvious to 
state, but are frequently made. Before applying energy values it is essential to consider, as a first step, the level at which the weights of foods are stated, for example whether the food is 'as produced', 'as purchased', 'edible portion' or 'as served'. Energy values must be chosen which are adjusted, by appropriate wastage allowances, to the required level. A similar source of error is failure to note the water content at which the average composition of the food is expressed. This error often arises in estimations of the energy value of flour. For example, the Food Composition Tables for International Use (Chatfield, 1949) give composition figures for flour which are geared to a $12 \%$ water content, whereas, flour composition in the United Kingdom is usually calculated on $15 \%$ water. A difference of this magnitude in moisture content causes a difference of about $\mathrm{I} 2 \mathrm{Cal} / \mathrm{/}$ oo $\mathrm{g}$ flour or about $55 \mathrm{Cal} / \mathrm{lb}$., a difference of over $3 \%$ in the energy value of flour.

The next group of difficulties might be termed difficulties of description. They always occur when foods of variable composition have to be fitted to average figures of composition. In estimating the energy value of food supplies a very frequent difficulty is that of deciding what should be the fat content of meat. For example, the fat content of the edible portion of beef may vary from $16 \%$ for stewing steak to $29 \%$ for grilling steak. There are also differences in protein and water content, but fat content has the controlling influence on the difference in energy value which amounts to about roo Cal./100 g (edible portion) between the two types of meat mentioned, or nearly $50 \%$ of the value for stewing steak. Variations of this order point to the importance of accurate descriptions if gross errors are not to be made in the application of tables of food composition. Perhaps even more difficult is the estimation of the energy value of made-up dishes unless the precise recipes and losses of weight on cooking are known.

In practice, it is usually assumed that if sufficient care is taken in the use of tables of food composition, errors arising from variations in composition and description will, at least on the average, be self-compensating. This is, however, an almost impossible assumption to test. In a small comparison made some years ago Bransby, Daubney \& King (1948-9) showed that the energy value of the diets of thirty-three adults over 3 days estimated by chemical analysis and by food tables (based on the same conventions) did not differ significantly: there were small differences for carbohydrate and protein, which largely cancelled each other.

The third group of difficulties raises controversial issues. According to various conventions carbohydrate has been expressed 'by difference', as 'available' carbohydrate in terms of starch or in terms of glucose or as a compromise between the two. Differences in carbohydrate content of $100 \mathrm{~g}$ of edible portion of certain foods are illustrated in Table r. The figures shown are taken from: Nutritive Values of Wartime Foods (Medical Research Council: Accessory Food Factors Committee, 1945), in which the values are expressed as starch; Chemical Composition of Foods (McCance \& Widdowson, 1946), in which the values are expressed as glucose; Tables of Representative Values of Foods Commonly Used in Tropical Countries compiled by Platt (1945), who used a compromise (C) between available carbohydrate by direct chemical analysis (AC) and carbohydrate by difference (CD) expressed 
by the formula $\mathrm{C}=\frac{1}{2}(\mathrm{AC}+\mathrm{CD}-\mathrm{F})$, derived by assuming that, after deducting fibre (F), one-half the carbohydrate not allowed for in the chemical analysis but included in the total carbohydrate estimated by difference is utilized by the body; and Food Composition Tables for International Use (Chatfield, 1949), in which the values are those obtained by difference, that is by subtracting the sum of the figures for water, protein, fat and ash per $100 \mathrm{~g}$ from roo.

Table I. Comparison of carbohydrate values for potatoes, flour and sugar derived by different calculations*

(Raw edible portion, g/roo g)

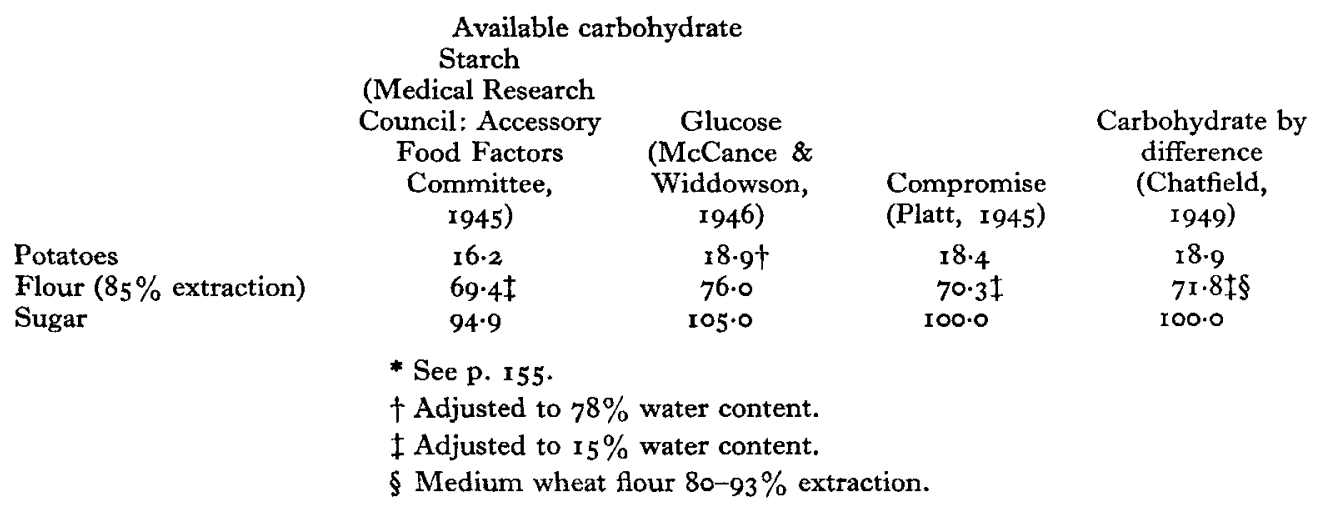

The energy value of the carbohydrate moiety of each of these foods calculated according to the convention adopted in each table of food composition is shown in Table 2.

Table 2. Energy value (Cal./100 g) of carbohydrate moiety of selected foods

$\begin{array}{lcccc} & \begin{array}{c}\text { Medical Research } \\ \text { Council: Accessory } \\ \text { Food Factors } \\ \text { Committee } \\ \text { (1945) }\end{array} & \begin{array}{c}\text { McCance \& } \\ \text { Widdowson } \\ \text { (1946) }\end{array} & \begin{array}{c}\text { Platt } \\ \text { (1945) }\end{array} & \begin{array}{c}\text { Chatfield } \\ \text { (1949) }\end{array} \\ \text { Potatoes } & 65 & 71 & 74 & 76 \\ \text { Flour (85\% extraction) } & 278 & 285 & 281 & 284 \\ \text { Sugar } & 380 & 394 & 400 & 387\end{array}$

These figures are shown merely to illustrate how easy it is, by using the tables of food composition commonly available, to derive totally different results for the energy contribution of the carbohydrate fractions of food.

Widdowson (1955) has given the history of the use from the time of Rubner and Atwater onwards of the various factors for the conversion of proximate principles to energy. My purpose is to present the results of using these different factors on mixed diets.

In 1936 Morey wrote 'the multiplicity of methods used in calculating the amounts 
of energy actually derived by the body from a given amount of food eaten or purchased, makes it extremely difficult to compare accurately dietary studies and standards' (Morey, 1936-7). She described the confusion which arose at the time over the use of the terms 'gross' and 'net' calories by workers in Europe and America, explaining that to the German or Scandinavian investigator 'gross calories' meant what might be called 'Rubner calories' in the food eaten; to the British investigator it seemed to mean 'Rubner calories' in the food as purchased; to the American investigator it meant either the heat of combustion of the food eaten, or the 'Atwater calories' in the food as purchased. The confusion now is considerably less than it was. I mention Morey's review merely to point out that the older text books and reports on nutritional subjects must be read with caution if the reader is not be to misled about the energy value of diets. In her review Morey showed the different ways in which the energy values of a diet containing $100 \mathrm{~g}$ protein, $80 \mathrm{~g}$ fat and $500 \mathrm{~g}$ carbohydrate would have been calculated in various countries at that time. Her table is reproduced below (Table 3).

Table 3. Results obtained by calculating the energy value of the diet* according to methods used in various countries

(From Morey, 1936-7)

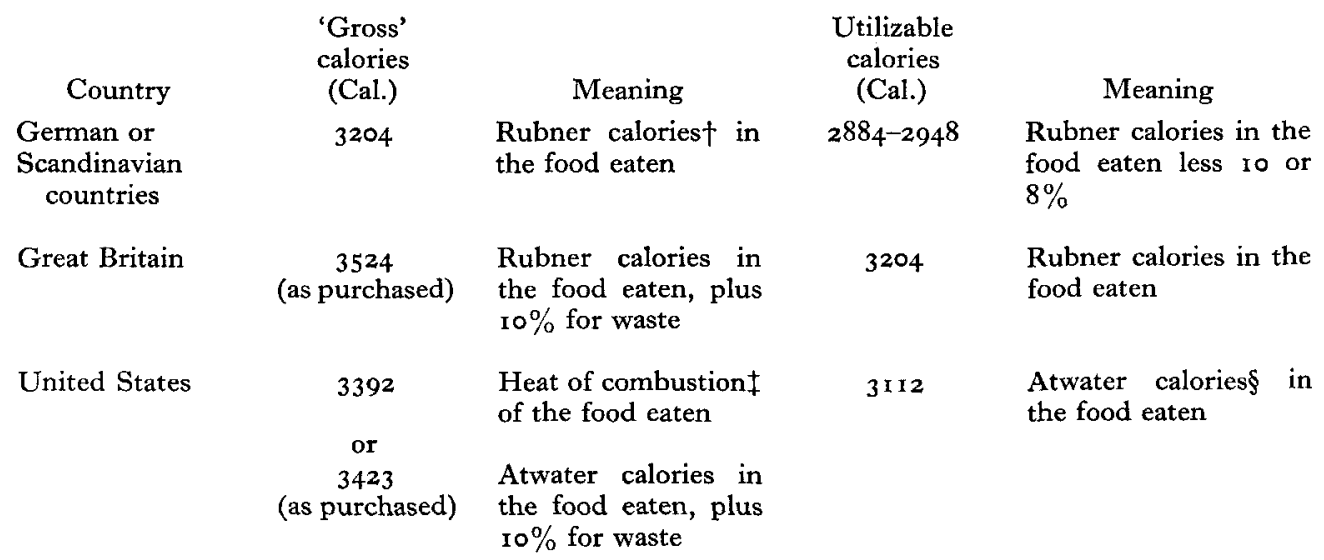

* Supposing the food eaten contained I00 g protein, $80 \mathrm{~g}$ fat, $500 \mathrm{~g}$ carbohydrate.

† Calories calculated by the use of Rubner factors $(4 . \mathrm{I}, 9.3,4 . \mathrm{I}$ for $\mathrm{I} g$ protein, fat and carbohydrate respectively).

$\ddagger$ Calories calculated by the use of Atwater's factors for heat of combustion of I $g$ protein, fat and carbohydrate in a mixed diet $(5 \cdot 65,9 \cdot 4,4 \cdot 15$ Cal. respectively).

$\S$ Calories calculated by the use of Atwater's factors for fuel value, which allows for losses in digestion $(4 \cdot 0,8.9,4.0$ for $\mathrm{I} g$ protein, fat and carbohydrate respectively).

(Footnotes $(\dagger)$ and $(\S)$ are reversed in the original paper).

In this calculation, the largest figures for gross and utilizable calories were $110 \%$ and II $\%$ of the smallest.

Maynard (1944) has pointed out that it is incorrect to apply Atwater's weighted factors 4,9 (or 8.9) and 4 to mixed diets unless these happen to be of the same constitution as the diets on which Atwater made his calculations. After the publication 
of Maynard's paper we made calculations (Ministry of Food, 1945) of the energy value of total British food supplies prewar and in 1943 and 1944 according to five conventions:

(I) that adopted by the Medical Research Council: Accessory Food Factors Committee (1945) which was used then and is used now for all official British statistics showing the energy value of British food supplies or domestic food consumption, namely, that all available carbohydrate shall be expressed as starch and that the factors 4,9 and 4 shall be applied per $g$ protein, fat and available starch;

(2) the modification suggested by Maynard (1944), that method (I) could be improved by using the factor 4.2 for available starch instead of 4 ;

(3) the use of Atwater's individual factors for protein and fat and the factor 4.2 for available starch;

(4) the use of the conventional factors $4,9,4$ for protein, fat, and carbohydrate by difference;

(5) the use of Atwater's individual factors for protein, fat, and carbohydrate by difference.

The results of the calculation are shown in Table 4 . The figures in line I are $1-4 \%$ lower than those in lines 3 or 5 , which are based on contemporary weighting of Atwater's factors and $2-3 \%$ lower than those in line 2 which represents the compromise suggested by Maynard.

Table 4. Energy value (Cal./head/day) of British food supplies calculated in various ways using Atwater's factors

\begin{tabular}{|c|c|c|c|}
\hline Method used & Prewar & I943 & I944 \\
\hline \multicolumn{4}{|l|}{$\begin{array}{l}\text { Available carbohydrate as } \\
\text { starch }\end{array}$} \\
\hline $\begin{array}{l}\text { Atwater \& Bryant } \\
\text { (1900) weighting } \\
(4: 9: 4)\end{array}$ & $3010^{*}$ & 2900* & $3000^{*}$ \\
\hline $\begin{array}{l}\text { Atwater } \& \text { Bryant (1900) } \\
\text { weighting with } \\
\text { modification for } \\
\text { starch }(4: 9: 4 \cdot 2)\end{array}$ & 3090 & 2980 & 3070 \\
\hline $\begin{array}{l}\text { Contemporary British } \\
\text { weighting with } \\
\text { modification for } \\
\text { starch }\end{array}$ & 3060 & $294^{\circ}$ & 3040 \\
\hline $\begin{array}{l}\text { Carbohydrate by } \\
\text { difference } \\
\text { Atwater \& Bryant } \\
(1900) \text { weighting } \\
(4: 9: 4)\end{array}$ & 3160 & 3060 & 3160 \\
\hline $\begin{array}{l}\text { Contemporary British } \\
\text { weighting }\end{array}$ & $3120^{*}$ & $2990^{*}$ & $3100^{*}$ \\
\hline
\end{tabular}

* The supply data on which these figures are based have subsequently been revised. These figures are, therefore, not precisely the same as the official published estimates (Ministry of Food, 1953). 
All official estimates of the energy value of British food supplies and domestic food consumption and estimates for replies to Parliamentary Questions and for other public statements within the United Kingdom are based on the values in 'Nutritive Values of Wartime Foods' (Medical Research Council: Accessory Food Factors Committee, 1945) and thus on the convention of available starch and factor 4.

The reports of the National Food Survey Committee (e.g. Ministry of Food: National Food Survey Committee, 1954) give estimates of the energy value of the diet of numerous groups of the population. It is known that these are likely to be underestimates, but it would be impracticable to attempt recalculation even if a new officially acceptable British table of food composition was available-and it is not. Comparability over time and between groups is essential, and when another British table has been compiled it will be necessary to duplicate our estimates to provide for an overlap.

The difficulty of making international comparisons of the nutritive value of total food supplies first became apparent during the 1939-45 war when attempts were made to compare supplies in the United States, Canada and the United Kingdom and it appeared that the American and Canadian methods of calculation gave results respectively 150 and $100 \mathrm{Cal}$./head/day (i.e. $5 \%$ and $3 \%$ ) greater than the British method. The matter is fully discussed in the report of the Combined Food Board (1944).

Difficulties arose later when comparisons were made between our own estimates of the energy value of British food supplies and those made by the Food and Agriculture Organization (c.f. Anonymous, r949), and it has been essential for us to produce internationally acceptable figures.

The procedure adopted for line 5 of Table 4 is in principle the same as that used for the compilation of Tables of Food Composition for International Use (Chatfield, 1949), which for several reasons are not directly applicable to British food supplies. The most important reasons are that flour composition is based on $12 \%$ moisture content; that no suitable composition figures are given for $80 \%$ extraction flour (the figures are for $80-93 \%$ extraction which is too wide a range for British practice); that the meat factors do not apply to meat anatomically similar to British

Table 5. Energy value (Cal./head/day) of British food supplies calculated according to methods of Medical Research Council: Accessory Food Factors Committee (1945) and F.A.O. (Chatfield, 1949)

$\begin{array}{lccc}\text { Year } & \text { M.R.C. } & \text { F.A.O. } & \begin{array}{c}\text { F.A.O. as } \\ \text { percentage } \\ \text { of M.R.C. }\end{array} \\ \text { Prewar } & 3000 & 3110 & 104 \\ 1940 & 2800 & 2910 & 104 \\ 1942 & 2870 & 2960 & 103 \\ 1944 & 3010 & 3110 & 103 \\ 1947 & 2880 & 2980 & 103 \\ 1950 & 3050 & 3150 & 103 \\ 1953 \text { (provisional) } & 3000 & 3110 & 104\end{array}$


meat supplies, and that there are no factors for bacon. We have, in consequence, prepared a table (see Table 5) of food composition according to the principles adopted by F.A.O. (Chatfield, r949) but arranged for application to British food supplies. We now use it for all calculations of the nutritive value of British food supplies for international comparisons. British total supply estimates for the years from prewar to I953 have been published (Ministry of Food, 1953; I954) in terms of the convention adopted by the Medical Research Council: Accessory Food Factors Committee (1945) and according to our adaptation of the F.A.O. table. The latter gives results $3-4 \%$ higher than the former (c.f. Fenelon, 1949). The difference would be greater for countries obtaining higher proportions of their energy supplies from carbohydrate. We have made calculations from F.A.O. Food Balance Sheets for I948/9 (Food and Agriculture Organization of the United Nations, 1950) of total energy value for Greece, Italy and Japan and found differences of the order of $5 \%$ between the two sets of estimates.

\section{REFERENCES}

Anonymous (1949). Economist, 157, 713.

Atwater, W. O. \& Bryant, A. P. (1900). Rep. Storrs agric. Exp. Sta. 1899, p. 73.

Bransby, E. R., Daubney, C. G. \& King, J. (1948-9). Brit. F. Nutr. 2, 232.

Chatfield, C. (1949). F.A.O. nutr. Stud. no. 3 .

Combined Food Board (1944). Food Consumption Levels in the United States, Canada and the United Kingdom. London: H.M. Stationery Office.

Fenelon, K. G. (1949). Economist, 157, 888.

Food and Agriculture Organization of the United Nations (r950). Food Balance Sheets, I948/9, Suppl. (Mimeo.).

McCance, R. A. \& Widdowson, E. M. (1946). Spec. Rep. Ser. med. Res. Coun., Lond., no. 235, 2nd ed. Maynard, L. A. (1 944). \%. Nutr. 28, 443 .

Medical Research Council : Accessory Food Factors Committee (1945). M.R.C. (War) Memor. no. I4. Ministry of Food (1945). Unpublished records.

Ministry of Food (1953). Bull. Minist. Fd, Lond., no. 720, p. 6.

Ministry of Food (1954). Bull. Minist. Fd, Lond., no. 755, p. 8.

Ministry of Food: National Food Survey Committee (1954). Domestic Food Consumption and Expenditure, 1952. London: H.M. Stationery Office.

Morey, N. B. (1936-7). Nutr. Abstr. Rev. 6, 1.

Platt, B. S. (1945). Spec. Rep. Ser. med. Res. Coun., Lond., no. 253.

Widdowson, E. M. (1955). Proc. Nutr. Soc. I4, I42. 